\title{
Correction to: Characteristic polyhedra of singularities without completion: part II
}

\author{
Vincent Cossart ${ }^{1} \cdot$ Bernd Schober ${ }^{1,2,3}$ (iD \\ Published online: 5 July 2021 \\ (c) The Author(s) 2021
}

\section{Correction to: Collectanea Mathematica (2021) 72:351-392. https://doi.org/10.1007/s13348-020-00291-5}

The article Characteristic polyhedra of singularities without completion: part II, written by Vincent Cossart, Bernd Schober was originally published Online First without Open Access.

After publication in volume 72, issue 2, pages 351-392, the author decided to opt for Open Choice and to make the article an Open Access publication. Therefore, the copyright of the article has been changed to The Author(s) 2021 and the article is forthwith distributed under the terms of the Creative Commons Attribution 4.0 International License, which permits use, sharing, adaptation, distribution and reproduction in any medium or format, as long as you give appropriate credit to the original author(s) and the source, provide a link to the Creative Commons licence, and indicate if changes were made. The images or other third party material in this article are included in the article's Creative Commons licence, unless indicated otherwise in a credit line to the material. If material is not included in the article's Creative Commons licence and your intended use is not permitted by statutory regulation or exceeds the permitted use, you will need to obtain permission directly from the copyright holder. To view a copy of this licence, visit http://creativecommons.org/licen ses/by/4.0.

The original article has been corrected.

The original article can be found online at https://doi.org/10.1007/s13348-020-00291-5.

Bernd Schober

bernd.schober@uni-oldenburg.de

Vincent Cossart

cossart@math.uvsq.fr

1 Laboratoire de Mathémathiques de Versailles CNRS UMR 8100, Université Paris-Saclay, 45 avenue des États-Unis, 78035 Versaills Cedex, France

2 Institut für Algebraische Geometrie, Leibniz Universität Hannover, Welfengarten 1, 30167 Hannover, Germany

3 Institut für Mathematik, Carl von Ossietzky Universität Oldenburg, 26111 Oldenburg, Germany 
Open Access This article is licensed under a Creative Commons Attribution 4.0 International License, which permits use, sharing, adaptation, distribution and reproduction in any medium or format, as long as you give appropriate credit to the original author(s) and the source, provide a link to the Creative Commons licence, and indicate if changes were made. The images or other third party material in this article are included in the article's Creative Commons licence, unless indicated otherwise in a credit line to the material. If material is not included in the article's Creative Commons licence and your intended use is not permitted by statutory regulation or exceeds the permitted use, you will need to obtain permission directly from the copyright holder. To view a copy of this licence, visit http://creativecommons.org/licenses/by/4.0/.

Publisher's Note Springer Nature remains neutral with regard to jurisdictional claims in published maps and institutional affiliations. 